Acta vet. scand. $1964,5,217-223$.

From the Department of Clinical Biochemistry, Royal Veterinary College, Stockholm, Sweden.

\title{
SECRETION OF RADIOIODINE IN MILK FOLLOWING A SINGLE ORAL ADMINISTRATION IN THE COW*)
}

By

Carl Bertil Thorell

The occurrence of radioiodine in milk in conjunction with atomic explosions and reactor accidents is now well known. A number of investigations on the secretion of radioiodine in milk have been done, particularly in Great Britain and the United States (for references, see Lengemann \& Comar, 1961). A corresponding investigation under Swedish conditions was motivated by the possibility of differences existing in forage contents between different countries and differences in the cows breed characteristics; such factors could influence the iodine metabolism.

\section{MATERIAL AND METHODS}

Carrier-free $I^{131}$ as sodium iodide in water solution was given in a single dose oral administration to two pregnant cows of the Swedish Red and White Breed, both of which were about four years old. Two and three experiments, respectively, were carried out on each cow, and the investigation was spread out over ten months with the first experiment occurring in June 1962. The administered dose of $I^{131}$ varied within the different experiments from 65 to $600 \mu \mathrm{C}$. The administration occurred in all experiments immediately after milking, while the time interval between the

*) The investigation was aided by grants from the Research Institute of National Defence, Swedish Agriculture Research Council, and the Swedish Atomic Research Council. 


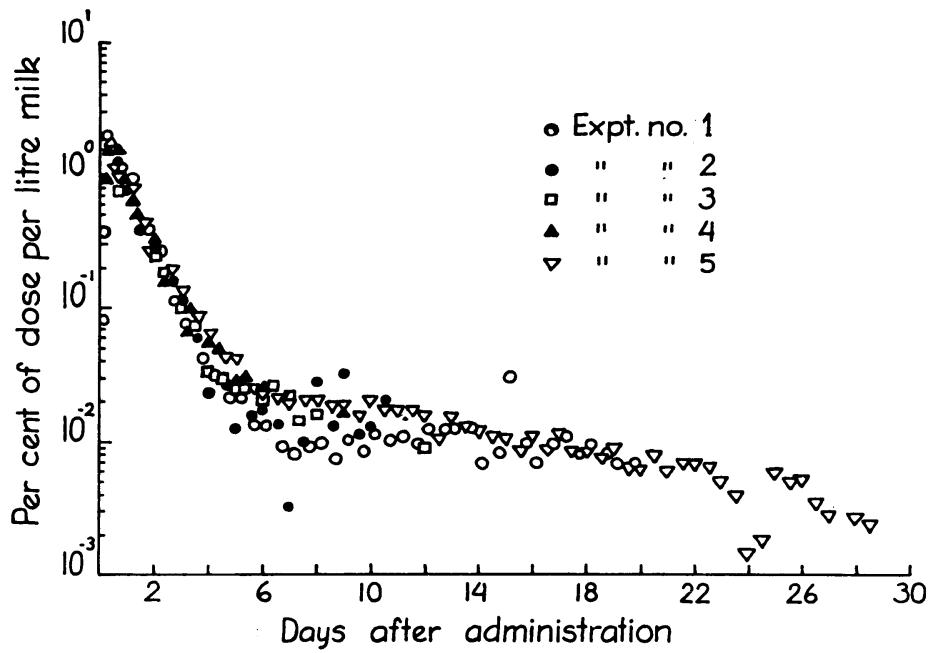

F i g u r e I. The concentration of $I^{131}$ per 1 of milk at every milking after single oral administrations. The amount of milk produced varied between 5.7 and 13.71 per day in the various experiments.

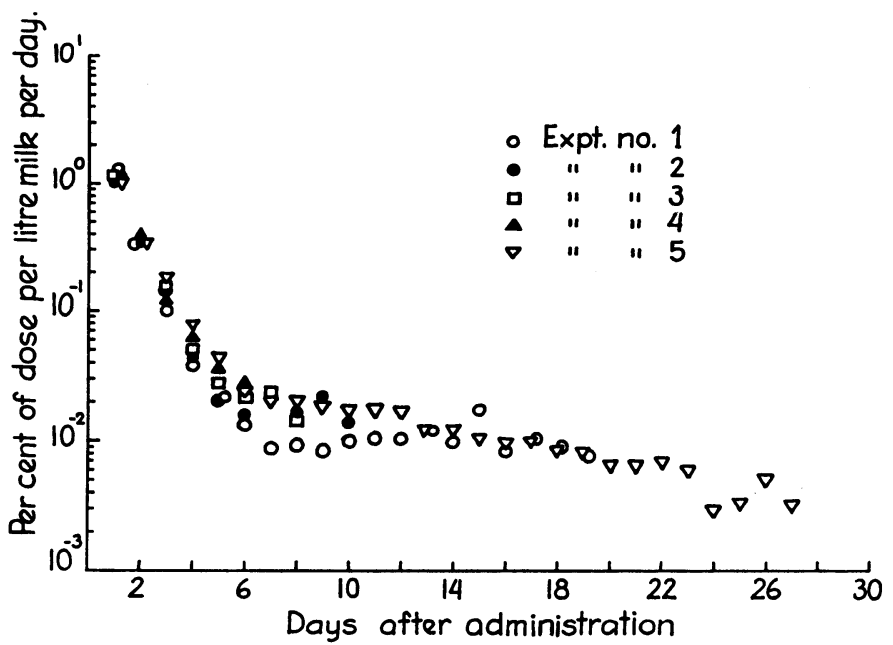

F i g u r e I I. The average concentration of $\mathrm{I}^{131}$ per $\mathrm{l}$ of milk per day after single oral administrations. The amount of milk produced varied between 5.7 and $13.7 \mathrm{l}$ per day in the various experiments. 
administration and the subsequent milkings varied in the different experiments. The animals stood in stalls on a farm in the Middle of Sweden and were fed home grown forage and molasses and salt-stone. The daily feed ration was clover-timothy hay, ad libitum, $12 \mathrm{~kg}$ ensilage, $7 \mathrm{~kg}$ grain supplement ( $1 / 3$ barley and $2 / 3$ oats), $0.5 \mathrm{~kg}$ molasses and free access to the salt lick.

The measurement of the radioactivity was done on $5 \mathrm{ml}$ milk samples with a thallium-activated sodium iodide well-crystal detector equipped with a single channel gamma-ray spectrometer. The amount of $\mathrm{I}^{131}$ in the milk, expressed as per cent of the given dose per 1 was calculated for every experiment using a known standard sample. On this basis, the values were corrected for the physical half-life of $I^{131}$. Milk from another cow in the same stable was used for measurements of the background.

\section{RESULTS}

As early as a half hour after administration, the radioiodine began to appear in the milk; so that 0.08 per cent of the given dose was recovered per 1 of milk. The maximal concentration was found in the milk which was obtained about six hours after the administration; the concentration of radioiodine per 1 of milk varied between 1.55 and 1.92 per cent (average 1.73 ) of the given dose. The subsequent reduction in concentration occurred relatively quickly until about six days after administration when the amount was 0.02 per cent of the given dose. (Figure I). A graphic analysis of the concentration curve shows that it follows a two exponential course corresponding to the biological half-life of 0.6 and 10 days, respectively. In figure II, the average concentration of $I^{131}$ per 1 of milk per day is shown for the various experiments. The total secretion through the milk of a single dose of $I^{131}$ in the various experiments is stated in table $I$ where the quotient between the total amount of $I^{131}$ in the milk and the amount of milk is given for the various experiments.

The values listed under "Results" together with the curves and the table are corrected for the physical half-life of $\mathbf{I}^{131}$.

\section{DISCUSSION}

The rapid appearance of radioiodine in the milk following administration is in accordance with the reports of Lengemann et al. (1955) and Garner \& Sansom (1959). The former recovered 
T a b l e I. The total secretion of $I^{131}$ through the milk after single dose administrations; expressed as per cent of given dose.

Total number of days after administration

Experiment number

\begin{tabular}{lllll} 
& \multicolumn{5}{c}{} & 6 & & \\
\hline 1 & 2 & 3 & 4 & 5
\end{tabular}

\begin{tabular}{lllll}
\multicolumn{4}{c}{8} \\
\hline 1 & 2 & 3 & 5
\end{tabular}

\begin{tabular}{lllll} 
& 10 & & \multicolumn{2}{c}{18} \\
\hline 1 & 2 & 5 & 1 & 5
\end{tabular}

Total secretion of $I^{131}$; per cent of given dose

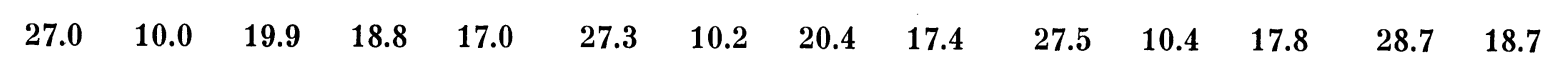

Total amount of milk

in 1

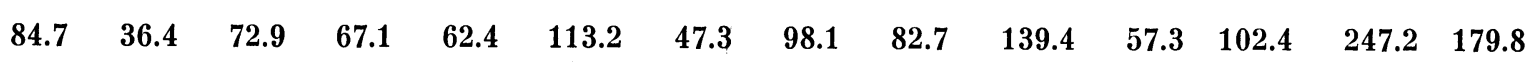

Total secretion of $\mathrm{I}^{131}$

\begin{tabular}{|c|c|c|c|c|c|c|c|c|c|c|c|c|c|c|}
\hline Total milk amount & 0.32 & 0.27 & 0.27 & 0.28 & 0.27 & 0.24 & 0.22 & 0.21 & 0.21 & 0.20 & 0.18 & 0.17 & 0.12 & 0.10 \\
\hline $\begin{array}{l}\text { Experimental cow } \\
\text { number }\end{array}$ & 1 & 1 & 2 & 2 & 2 & 1 & 1 & 2 & 2 & 1 & 1 & 2 & 1 & 2 \\
\hline Month & June & Sept. & Dec. & Jan. & March & June & Sept. & Dec. & March & June & Sept. & March & June & March \\
\hline
\end{tabular}


about 0.02 per cent of given dose in the milk thirty minutes after administration. Squire et al. (1958) and Garner \& Sansom (1959) found that the maximal concentration in the milk occurred at approximately twelve hours after administration; while Lengemann \& Comar (1961) found that it occurred within three to four hours after administration. The literature gives no clear description of how large the maximal concentration per 1 of milk is, but isolated values from the tables and figures give variations between 0.3 per cent (Garner \& Sansom 1959) and slightly more than one per cent (Lengemann et al. 1957; Garner 1959). These values are significantly lower than those found in this investigation. The subsequent diminishing of the concentration is in accordance with the statements of Garner \& Sansom (1959); namely, that the concentration of radioiodine in the milk six days after administration was one to two per cent of the maximum value and that the concentration in the beginning diminished by 50 per cent within 15-20 hours. Glascock (1954) found that the concentration in the milk diminished by 50 per cent for about each 36 hour period between the first and the ninth day. Squire et al. (1958) found that the concentration in the milk six days after administration was three to four per cent of the maximum concentration. Lengemann \& Swanson (1957) report a reduction in the concentration of 50 per cent at 1.25 and 1.35 days, respectively in two cows; while Lengemann et al. (1957) state that corresponding lessening of the concentration occurs at one half day. A two exponential secretion curve was obtained in this investigation; the biological half-life of radioiodine in the above mentioned rapid secretion phase was 0.6 days.

The total secretion of $\mathrm{I}^{131}$ through the milk was seen, in this investigation, to be dependent upon the amount of milk production. Garner et al. (1960) found this also, along with a correlation between the amount of radioiodine and the amount of milk production which was significant at the one per cent level. Squire et al. (1958) says that the regression is significant at the five per cent level. Lengemann et al. (1955) report, however, that the total secretion is completely independent of the production. The total secretion of radioiodine in the present investigation was high in comparison with the information reported in the literature. Squire et al. (1958) found, during a total of six days, between 1.25 and 13.1 per cent of the given dose of $I^{131}$ in the milk, and Garner \& Jones (1960) found between 3.6 and 19.7 
per cent during a 14 day period. Other values in the literature are between the above mentioned extremes of 1.25 and 19.7 per cent. Lengemann et al. (1957) showed that the total secretion varied during different periods of the year; while Garner \& Sansom (1959) did not find any such variations. The present investigation, though the stated material is small, furnished no seasonally related variation in the total secretion of radioiodine in the milk.

The reason for the comparatively large secretion of $I^{131}$ in the milk in this investigation following a single oral dose is not clear. Many factors may have an influence; for example, the content of stable iodine in the feed and breed characteristics of the Swedish Red and White Breed.

\section{REFERENCES}

Garner, R. J.: Radiobiology: the metabolism of iodine and strontium in cows. Vet. Rec. 1959, 71, 982-989.

Garner, R. J. \& Jones, H. G.: Fission products and the dairy cow. IV. The metabolism of $\mathrm{I}^{131}$ following single and multiple doses. J. agric. Sci. 1960, 55, 387-390.

Garner, R. J. \& Sansom, B. F.: Transfer of iodine-131 and strontium-89 from diet to milk in cattle. Vet. Rec. 1959, 71, 670-673.

Garner, R. J., Sansom, B. F. \& Jones, H. G.: Fission products and the dairy cow. III. Transfer of 131iodine to milk following single and daily dosing. J. agric. Sci. $1960,55,283-286$.

Glascock, R. F.: The secretion of a single tracer dose of labelled iodide in the milk of the lactating cow. J. Dairy Res. 1954, 21, 318-322.

Lengemann, F. W. \& Comar, C. L.: Mechanisms of transfer of radionuclides from the environment through food, air and water to man. d. Domestic animals. The metabolism of some fission products by farm animals. FAO/WHO/IAEA seminar on the agricultural and public health aspects of radioactive contamination in normal and emergency situations; Scheveningen, The Netherlands; $11-15$ December, 1961.

Lengemann, F. W., Monroe, R. A. \& Swanson, E. W.: The secretion of $I^{131}$ in milk. J. Dairy Sci. 1955, 38, 619.

Lengemann, F. W. \& Swanson, E. W.: A study of the secretion of iodine in milk of dairy cows, using daily oral doses of $\mathrm{I}^{131}$. J. Dairy Sci. 1957, 40, 216-224.

Lengemann, F. W., Swanson, E. W. \& Monroe, R. A.: Effect on season of iodine in milk. J. Dairy Sci. 1957, 40, 387-393.

Squire, H. M., Middleton, L. J., Sansom, B. F. \& Coid, C. R.: Experiments on the metabolism of certain fission products in dairy cows. Radioisotopes in Scientific Research, Pergamon Press, 1958, 4, 207-220. 


\section{SUMMARY}

The secretion of radioiodine in the milk following the administration of a single oral dose was studied using $I^{131}$. All of the values are corrected for the physical decay of the isotope.

I 131 began to appear in the milk 30 minutes after administration with a maximal concentration of, on the average, 1.7 per cent of the given dose per 1 of milk at about six hours following administration. The subsequent reduction in the concentration showed a two exponential course with biological half-lives of 0.6 days and 10 days, respectively. The total secretion in the milk was between 10 and 27 per cent of the given dose of $\mathrm{I}^{131}$ in six days. The total secretion of radioiodine in the milk was seen to be dependent upon the cow's milk production.

\section{ZUSAMMENFASSUNG}

Die Ausscheidung von Radiojod in der Milch nach einmaliger Gabe per os bei Kuh.

Die Ausscheidung von Radiojod in der Milch nach einmaliger Gabe per os bei Kuh wurde mit $\mathrm{J}^{131}$ studiert. Sämtliche Werte wurden för den physikalischen Zerfall des Isotopes korrigiert.

$\mathrm{J}^{131}$ begann 30 Minuten nach der Eingabe in der Milch aufzutreten und hatte eine maximale Konzentration, mit einem Mittelwert von 1,7 Prozent der gegebenen Dosis per Liter Milch, sechs Stunden nach der Eingabe. Die darauffolgende Konzentrationsabnahme zeigte einen zweiexponentiellen Verlauf mit den biologischen Halbierungszeiten von 0,6 Tagen bezw. 10 Tagen. Totalt wurde zwischen 10 Prozent und 27 Prozent der gegebenen Menge $\mathrm{J}^{131}$ mit der Milch unter sechs Tagen ausgeschieden. Die Gesamtausscheidung von Radiojod in der Milch schien von der Milchproduktion der Kuh abhängig zu sein.

\section{SAMMANFATTNING}

Utsöndring av radiojod $i$ mjölk efter per oral engångsgiva åt ko.

Utsöndringen av radiojod $i$ mjölken efter per oral engångsgiva åt ko har studerats med J131. Samtliga värden har korrigerats för isotopens fysikaliska sönderfall.

$\mathrm{J}^{131}$ började uppträda $\mathrm{i}$ mjölken 30 minuter efter ingivningen och med en maximal koncentration av i medeltal 1,7 procent av given dos per liter mjölk omkring sex timmar efter ingivningen. Den efterföljande koncentrationsminskningen visade ett tvåexponentiellt förlopp med biologiska halveringstider på 0,6 dygn respektive 10 dygn. Totalt utsöndrades med mjölken mellan 10 procent och 27 procent av given mängd $I^{131}$ på sex dygn. Totalutsöndringen av radiojod i mjölken syntes vara beroende av kons mjölkproduktion.

(Received September 21. 1963). 